DOI: $10.14451 / 2.150 .68$

\title{
АДМИНИСТРАТИВНО-ПРАВОВОЕ РЕГУЛИРОВАНИЕ ЧАСТНОЙ ДЕТЕКТИВНОЙ ДЕЯТЕЛЬНОСТИ В США (НА ПРИМЕРЕ ОТДЕЛЬНЫХ ШТАТОВ США)
}

\author{
(C) 2020 Лаврова Лилия Вадимовна \\ аспирант кафедры административного и финансового права юридического института \\ Российский университет дружбы народов, Россия, Москва \\ E-mail: Lilia.lavrova777@mail.ru
}

В настоящей работе проводится анализ законодательства о частной детективной деятельности отдельных штатов США. Автором выбрано законодательство штатов Луизианы, Невады, Нью Джерси и Миннесоты в связи с наибольшей развитостью в указанных штатах института частной детективной деятельности.

В рамках настоящей работы было исследовано понятие частной детективной деятельности и особенности ее административного регулирования. Автор отмечает, что во всех штатах США для осуществления частной детективной деятельности требуется получение лицензии.

Ключевые слова: частная детективная деятельность, частный детектив, частный следователь, административное регулирование, лицензирование, устав, административные правила, расследование.

Регулирование частной детективной деятельности в США относится к ведению штатов. Это означает, что в каждом штате США существуют собственные нормативные правовые акты, определяющие не только порядок осуществления данной деятельности, но и устанавливающие требования к лицам, претендующим получить статус частного детектива.

Следует отметить, что нормативные правовые акты, регулирующие деятельность частных детективов в США, характеризуются разноаспектным характером и большой пестротой. При этом речь может идти как о специальном законе, например, законе о частной детективной деятельности в штате Нью Джерси, так и актах, носящих общий характер, в которых к частной детективной деятельности может относится только глава либо несколько разделов. В последнем случае речь может идти об уставе какого-либо штата США.

Однако не смотря на отличия в форме правового регулирования частной детективной деятельности в штатах США, в указанных актах есть и много общего. Так, частная детективная деятельность в США относится к лицензируемому виду деятельности, для осуществления которой требуется получение специального разрешения. Для получения указанной лицензии действующее законодательство штатов США устанавливает требования, которым должен соответствовать частный детектив. Помимо указанных требований, законодательство штатов США достаточно скрупулезно регламентирует содержание частной детективной деятельности, устанавливая, как правило, исчерпывающий перечень видов услуг, оказываемых частными детективами.

Как представляется, особенность регулирования частной детективной деятельности в США может быть проиллюстрирована законодательством отдельных штатов.

a) Частная детективная деятельность в штате Миннесота

Частная детективная деятельность в штате Миннесота регулируется главой 7506 Административных правил Устава штата (PrivateDetecti vesAndProtectiveAgents).

В соответствии с подразделом 1 раздела 326.338 Административных правил Устава штата Миннесоты под частной детективной деятельностью следует понимать деятельность лица, которое за вознаграждение осуществляет сбор необходимой информации для другого лица [1].

Согласно разделу 326.338 Административных правил частные детективы вправе осуществлять следующие действия:

- проводить расследования преступлений как готовящихся, так и совершенных. При этом, отмечается, что разновидности преступлений могут носить самый широкий характер, в том 
числе, угрожающие правительству Соединенных Штатов либо любому штату, округу или муниципальномуобразованию;

- производить задержание лиц, подозреваемых в совершении преступлений или правонарушений;

- изучать личность, его привычки, поведение, репутацию, местонахождение;

- проводить анализ совершенных сделок лица;

- заниматься поиском свидетелей или других лиц, показания которых необходимы для расследования преступления или для разрешения дела в судах;

- заниматься поиском утраченного или похищенного имущества;

- расследовать факты произошедших несчастных случаев и пр. [2]

Для осуществления деятельности частного детектива требуется лицензия. Порядок предоставления лицензии для осуществления частной детективной деятельности регламентируется разделом 7506.0130Административных правил Устава штата Миннесоты. Лицом, осуществляющим лицензирование является Совет частных детективов и охранных агентов в лице образованного в нем Правления.

Для получении лицензии требуется оплатить лицензионный сбор, собрать необходимые документы, написать заявление и пройти собеседование, в рамках которого Советом частных детективов и охранных агентов может быть запрошена дополнительная информация.

Следует отметить, что соискатель лицензии должен обладать соответствующей квалификацией, а также пройти обучение обращения с огнестрельным оружием, знать стандарты применения оружия, уметь оказывать первую медицинскую помощь.

b) Частная детективная деятельность в штате Нью Джерси

В штате Нью Джерси детективная деятельность регулируется законом, принятым в 1939 году, о частных детективах (Private Detective Act).

Согласно ст. 45:19-9 закона о частных детективах под частной детективной деятельностью следует понимать проведение за вознаграждение любого расследования или расследований в целях установления следующих обстоятельств:

- совершение преступления или угрозы его совершения;
- поиск свидетелей;

- поиск и определение места нахождения лиц безвестно пропавших;

- установление места нахождения похищенного имущества;

- наблюдение за лицом в целях установления необходимых фактов;

- установление причины пожаров, несчастных случаев;

- определение аффилированности лица к другим лицам;

- сбор доказательств, которые будут использоваться правоохранительными органами или в судебном разбирательстве по гражданскому или уголовному делу [3].

Согласно 45:19-10 названного закона частная детективная деятельность в штате Нью Джерси не может осуществляться без лицензии.

Лицом, осуществляющем выдачу лицензии, является суперинтендант штата Нью Джерси.

При этом, закон штата Нью Джерси в отличии от административных правил Устава штата Миннесоты, предъявляет достаточно жесткие требования для получения лицензии.

Так, например, согласно ст. 45:19-11 «любое лицо, фирма, ассоциация или корпорация, желающая вести частный детективный бизнес должно подать в офис суперинтенданта письменное заявление, должным образом подписанное, приложив письменное одобрение не менее пяти авторитетных граждан, проживающих в одном округе с заявителем» [4].

Для получении лицензии требуется уплатить лицензионный сбор, который в отношении физического лица составляет 250 долларов США, в отношении ассоциации и корпорации 300 долларов США.

Лицензия может быть выдана лицу, достигшему 25 летнего возраста, который является гражданином США и постоянно проживает на территории штата Нью Джерси. Для получения лицензии на осуществление детективной деятельности ассоциацией и корпорацией установлено, что директор или его заместитель должен обладать пятилетним опытом работы в качестве следователя или сотрудника полиции в полицейском департаменте штата.

с) Частная детективная деятельность в штате Луизиана

Частная детективная деятельность в штате Луизианы регулируется законом о частных сле- 
дователях (Private Investigators Law).

При этом, необходимо отметить, что частный детектив и частный следователь по смыслу указанного закона относятся к синонимичным понятиям.

Согласно п.8 ст. 3503 под частным следователем следует понимать любое лицо, которое на основании полученной лицензии вправе проводить расследования с целью получения следующей информации:

- о совершенных преступлениях;

- о месте нахождения лица либо его имущества;

- о финансовом рейтинге и кредитоспособности лица, с которым предстоит совершить сделку;

- о причинах пожара, причиненном ущербе, а также прочих утратах имущества и пр. [5]

Частная детективная деятельность в штате Луизиана относится к категории лицензируемой деятельности, которую осуществляет Государственныйсовет частных следователей и экспертов.

Согласно ст. 3503 вышеназванного закона в получении лицензии может быть отказано следующим лицам:

- не достигшим возраста совершеннолетия;

- не являющимся гражданином Соединенных Штатов Америки;

- осужденным за совершение преступлений или аморальных поступков;

- страдающим психическим заболеванием;

- являющимся хроническим алкоголиком или наркоманом.

Статья 3507.2 закона о частных следователях штата Луизианы предусматривает несколько типов лицензий.

а) лицензия «privateinvestigationagencylicen se», выдаваемая частному детективному агентству для осуществления расследований в целях поучения информации, предусмотренной п.8 ст. 3503 вышеназванного закона;

b) лицензия «privateinvestigatorlicense», выдаваемая частному детективу для осуществления частной детективной деятельности;

с) лицензия «apprentice license» именуемая ученической. Основное содержание которой сводится к совершению лицензиатом отдельных действий, предусмотренных в п. 8 ст. 3503 закона о частных следователях, например, проведение расследований о пропаже имущества, установление его места нахождения и пр.

\section{d) Частная детективная деятельность в штате Невада}

В штате Невада положения о частной детективной деятельности содержаться в 648 главе Устава штата. Указанная глава содержит положения о частных следователях, частных патрульных, экспертах и прочих лиц, содействующих правоохранительной деятельности.

Следует отметить, что закон использует термин «Private Investigators», придавая ему синонимичное с частным детективом значение.

В соответствии с подразделом 648.012 Устава штата Невада частным следователем выступает лицо, которое вправе осуществлять расследование по установлению необходимых для заказчика фактов, как то: установление причин дорожно-транспортных происшествий, поиск и сбор доказательств, необходимых для использования в суде, установление места нахождения личности или имущества и пр. [6]

Частная детективная деятельность в штате Невада также как и в других штатах США подлежит обязательному лицензированию.

Органом, осуществляющим лицензирование частной детективной деятельности, является лицензионный Совет, назначаемый губернатором штата.

Согласно подразделу 648.060 Устава штата Невада ни одно лицо не можетзаниматься деятельностью частного детектива, в том числе рекламировать свой бизнес без наличия лицензии.

Для получения лицензиисогласно пп.2 подраздела 648.060 Устава штата Невадытребуется достижение возраста не менее 18 лет, быть гражданином США, а также обладать устойчивыми моральными принципами.

Лицензионный Совет может отказать в выдаче лицензии при наличии одного из следующих обстоятельств:

а) если соискатель совершил преступление либо мошенничество, сфальсифицировав документы для получения лицензии;

b) если соискатель указал недостоверные сведения о себе при подаче заявления для получения лицензии;

с) был сотрудником, директором, партнером или руководителем любой фирмы, партнерства, ассоциации или корпорации, которым было отказано в лицензии либо лицензия была отозвана [7].

Отмечается, что лицензионный Совет может также установить требования к сдачи теоре- 
тического экзамена по программе подготовки значение отводится подготовке лицензиатов обчастных детективов, в рамках которой большое ращению и применению огнестрельного оружия.

\section{Библиографический список}

1. Административные правила Устава штата Миннесоты (Private Detectives And Protective Agents). Официальный сайт штата Миннесоты (США) // https://www.revisor.mn.gov/rules/7506.0100/.

2. Административные правила Устава штата Миннесоты (Private Detectives And Protective Agents). Oфициальный сайт штата Миннесоты (США) // https://www.revisor.mn.gov/rules/7506.0100/.

3. Private Detective Act of 1939 // https://www.njsp.org/private-detective/index.shtml (официальный сайт полиции штата Нью Джерси).

4. Private Detective Act of 1939 // https://www.njsp.org/private-detective/index.shtml (официальный сайт полиции штата Нью Джерси).

5. Закон о частных следователях в штате Луизиана (Private Investigators Law) // http://sbpie.com/lawpi. aspx\#definitions

6. Официальный сайт штата Невада (США) https://law.justia.com/codes/nevada/2010/title54/chapter648/nrs648012.html.

7. Официальный сайт штата Невада (США) https://law.justia.com/codes/nevada/2010/title54/chapter648/nrs648012.html. 